\title{
Synthesis of Copper Sulfide Nanowhisker via Sonochemical Way and its Characterization
}

\author{
Changqi Xu, Zhicheng Zhang,* Qiang Ye, and Xiong Liu \\ Department of Polymer Science and Engineering, University of Science and Technology of China, Hefei, Anhui 230026, P. R. China
}

(Received September 26, 2002; CL-020847)

An ultrasonic irradiation route (USI route) is developed to synthesize whisker-like copper sulfide $\left(\mathrm{Cu}_{9} \mathrm{~S}_{8}\right)$ nanocrystals via the reaction between copper sulfate pantahydrate $\left(\mathrm{CuSO}_{4} \cdot 5 \mathrm{H}_{2} \mathrm{O}\right)$ and thioacetamide $\left(\mathrm{CH}_{3} \mathrm{CSNH}_{2}\right)$ in an aqueous solution at room temperature under ambient pressure. XRD, TEM, UV-vis and PL spectra are used to characterize the obtained product. A possible reaction process is suggested in the end of this paper.

In the past decades, the synthesis and characterization of nanometer-sized semiconductor transition metal chalcogenides and nitrides, for instances, nanosized $\mathrm{CdS}, \mathrm{ZnS}, \mathrm{PbS}, \mathrm{GaN}$, and InP have been attracting an increasing interest because of their excellent physical and chemical properties, ${ }^{2}$ which are not available in their bulk material. Specially, low dimension nanocrystals of these materials, nanosized rods, wires, tubes, ribbons, belts, and whiskers of chalcogenides and nitrides have potential application as quantum dots materials in photoelectron transformation devices because of their wonderful photoelectric properties. ${ }^{3}$ In order to obtain the desired nanosturcural materials, various ways have been developed; namely, chemical vapor deposition (CVD) method, soft template way, hard template way, solvothermal route, irradiation method, electrochemical method, and so forth. ${ }^{4-9}$

Copper sulfides are important types of minerals of copper. Some copper sulfides are p-type semiconductors. ${ }^{10} \mathrm{Cu}_{2-x} \mathrm{~S}$, a fast superionic conductor with structural disorder, ${ }^{11}$ is a promising material for thermoelectric and photoelectric transformers and high temperature thermistors. ${ }^{12} \alpha-\mathrm{Cu}_{2} \mathrm{~S}$ has been used in $\mathrm{p}-\mathrm{Cu}_{2} \mathrm{~S} /$ $\mathrm{n}-\mathrm{CdS}$ solar cells. ${ }^{3 \mathrm{a}, 13} \mathrm{CuS}$ shows metallic conductivity and transforms at $1.6 \mathrm{~K}$ into a superconductor. ${ }^{14}$ Generally, copper sulfide can be obtained by traditional solid-state reactions and self-propagating high temperature synthesis. ${ }^{9}$ Recently, many methods are developed to synthesize them, such as CVD method and hydrothermal process. ${ }^{7 \mathrm{~b}}$

Ultrasonic is a high frequency sound waves with high energy that can generate instantaneously local high temperature as high as $5000 \mathrm{~K}$ and local high pressure as high as 500 atm in called "cavitation" in the solution where ultrasonic irradiation pass through. ${ }^{15}$ Recently, as a new technology, ultrasonic wave has been utilized to produce many materials such as amorphous metals, alloy, selenides, carbides, phosphides, and nanocomposites which need rigorous preparation condition. ${ }^{5}$

In this study we synthesized nanosized whisker-like copper sulfide in aqueous solution employing ultrasonic wave and investigated its optical property.

All of used reagents are A.R. grade. A typical process is as follows: $2 \mathrm{mmol}$ copper sulfate pantahydrate $\left(\mathrm{CuSO}_{4} \cdot 5 \mathrm{H}_{2} \mathrm{O}\right.$, $>99.5 \%$, wt $\%)$ and $3 \mathrm{mmol}$ thioacetamide $\left(\mathrm{CH}_{3} \mathrm{CSNH}_{2}\right)$ are dissolved in $50 \mathrm{ml}$ distilled water. An appropriate amount of ammonia solution is added to adjust $\mathrm{pH}$ value to ca. 10. This solution is placed into an ultrasonic pool (Xinzhi Co., China, Ti- horn, $20 \mathrm{kHz}, 60 \mathrm{~W} / \mathrm{cm}^{2}$ ) for $6 \mathrm{~h}$ after bubbling 15 min with $\mathrm{N}_{2}$. The temperature goes up to about $70-75^{\circ} \mathrm{C}$ during reaction. The color of solution changes from dark blue to black and black precipitate appears in the bottom of the reactor. The precipitate is collected and washed several times with distilled water and ethanol in turn and dried for $4 \mathrm{~h}$ in a vacuum desiccator at $50^{\circ} \mathrm{C}$.

To investigate the structure, $\mathrm{X}$-ray diffraction $\left(\mathrm{XRD}^{1}\right)$ is carried out. XRD pattern of as-prepared sample is given in Figure 1. By comparison with the data from JCPDS file No. 36-379, its diffraction pattern can be indexed as the hexagonal crystal system copper sulfide $\left(\mathrm{Cu}_{9} \mathrm{~S}_{8}\right)$. The diffraction peaks are recognized as showed in Figure 1. To investigate the effect of solvent on morphology of $\mathrm{Cu}_{9} \mathrm{~S}_{8}$, we produced $\mathrm{Cu}_{9} \mathrm{~S}_{8}$ nanocrystals in mixed solvent of $25 \mathrm{ml}$ water and $25 \mathrm{ml}$ ethanol. Its diffraction peaks appear at the same degrees which indicates the same composition. But the less integrated and unsharp peaks of $\mathrm{Cu}_{9} \mathrm{~S}_{8}$ prepared in $\mathrm{H}_{2} \mathrm{O}$ compared with one prepared in EtOH show that its low dimensional growth of crystals, specially in (0022), (0013) and (1124) planes.

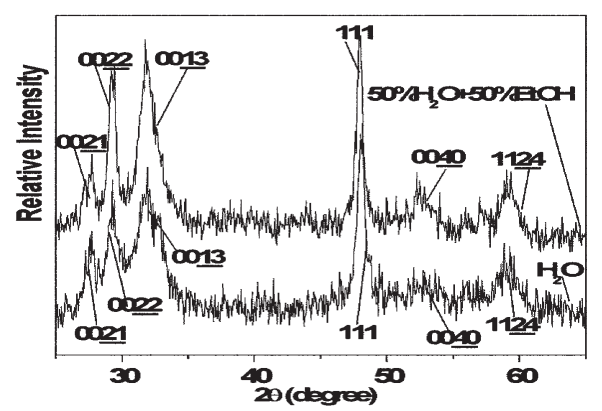

Figure 1. The XRD patterns of as-synthesized copper sulfides.

To investigate the morphology of samples as-prepared, we performed transmission electron microscope $\left(\mathrm{TEM}^{1}\right)$ study on it. Figure 2 gives the TEM images of samples. Figure 2a is TEM image of $\mathrm{Cu}_{9} \mathrm{~S}_{8}$ prepared in $\mathrm{H}_{2} \mathrm{O}$. Nanosized whisker-like $\mathrm{Cu}_{9} \mathrm{~S}_{8}$ crystals with width ca. 10-30 nm and length up to ca. $800 \mathrm{~nm}$ were found. The inset is its EDSA picture. Figure $2 b$ is TEM image of $\mathrm{Cu}_{9} \mathrm{~S}_{8}$ synthesized in the mixed solvent. Irregular shape $\mathrm{Cu}_{9} \mathrm{~S}_{8}$ nanocrystals can be found in it. The inset is its EDSA picture. The same EDSA pictures in Figures $2 \mathrm{a}$ and $2 \mathrm{~b}$ mean that they have consistent ingredient. We suppose the polarity difference in the two reaction mediums is responsible for the difference in morphology between them. In samples prepared in $\mathrm{H}_{2} \mathrm{O}$, some star-like $\mathrm{Cu}_{9} \mathrm{~S}_{8}$ can be found as shown in Figure 2c. A clearer structure picture of star-liked $\mathrm{Cu}_{9} \mathrm{~S}_{8}$ is inserted in Figure 2c.

To obtain optical information about $\mathrm{Cu}_{9} \mathrm{~S}_{8}$, UV-vis spectrophotometer $\left(\mathrm{UV}-\mathrm{vis}{ }^{1}\right)$ and fluorescence spectrophotometer $\left(\mathrm{PL}^{1}\right)$ were used to characterize samples and the spectra obtained are shown in Figure 3. In their UV-vis absorption spectra, both have a wide absorption shoulder from $600 \mathrm{~nm}$ to $500 \mathrm{~nm}$, agreeing with 


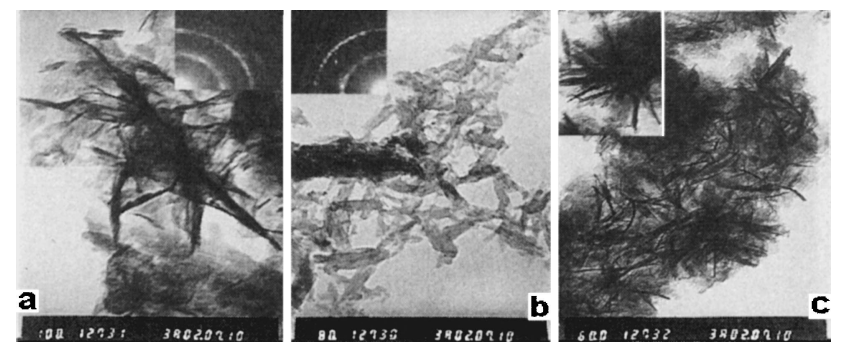

Figure 2. The TEM images of as-synthesized copper sulfides: a) $\mathrm{Cu}_{9} \mathrm{~S}_{8}$ prepared in $\mathrm{H}_{2} \mathrm{O}$; b) $\mathrm{Cu}_{9} \mathrm{~S}_{8}$ prepared in the mixed solvent; c) star-liked $\mathrm{Cu}_{9} \mathrm{~S}_{8}$ prepared in $\mathrm{H}_{2} \mathrm{O}$.

the literature value ${ }^{16}$ for $\mathrm{Cu}_{9} \mathrm{~S}_{8}$ nanoparticles that do not assemble to form whisker-like crystal. However, for whisker-like $\mathrm{Cu}_{9} \mathrm{~S}_{8}$ the other absorption appears at $250 \mathrm{~nm}$, which may be attributable to low dimension of whisker-like $\mathrm{Cu}_{9} \mathrm{~S}_{8}$. In the PL spectrum for whisker-like $\mathrm{Cu}_{9} \mathrm{~S}_{8}$ which inserted in top right corner in Figure 3, the strongest fluorescence relative intensity resulting from recombination of electrons and holes in the surface states, indicating the quantum size, appears at $310 \mathrm{~nm}$ when the excitation wavelength is $256 \mathrm{~nm}$. But there is no fluorescence phenomenon when the excitation wavelength changes from $200 \mathrm{~nm}$ to $700 \mathrm{~nm}$ for one obtained in the mixed solvent.

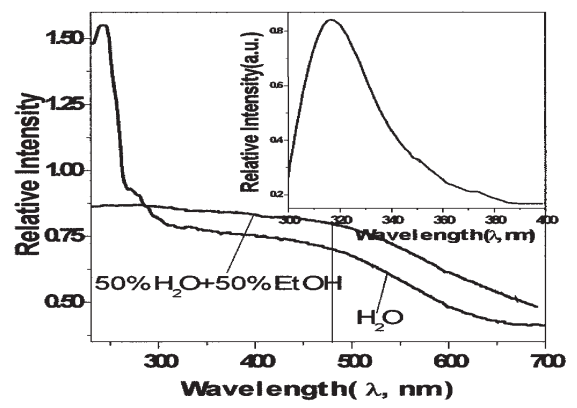

Figure 3. The UV-vis and PL spectra of as-synthesized copper sulfides.

The possible reaction process for forming $\mathrm{Cu}_{9} \mathrm{~S}_{8}$ nanowhisker with ultrasonic route can be described as follows:

$$
\begin{aligned}
& \mathrm{Cu}^{2+}+4 \mathrm{NH}_{3} \longrightarrow\left[\mathrm{Cu}\left(\mathrm{NH}_{3}\right)_{4}\right]^{2+} \\
& \left.\left.\left.\left.\mathrm{CH}_{3} \mathrm{C}-\mathrm{NH}_{2}+\mathrm{H}_{2} \mathrm{O}()\right) \cdots()\right)\right) \infty \stackrel{\mathrm{S}}{\mathrm{SH}}\right) \rightarrow \underset{\mathrm{OH}}{\mathrm{C}}-\mathrm{NH}_{2}
\end{aligned}
$$

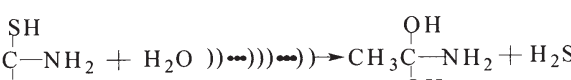

$$
\begin{aligned}
& \mathrm{OH} \quad \mathrm{OH}
\end{aligned}
$$

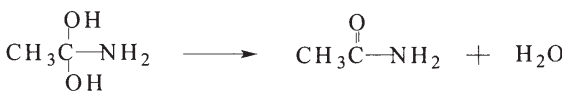

$$
\begin{aligned}
& \left.\left.\left.\left.\left.\left.9 n\left[\mathrm{Cu}\left(\mathrm{NH}_{3}\right)_{4}\right]^{2+}+8 \mathrm{nH}_{2} \mathrm{~S} \quad\right)\right) \ldots\right)\right)\right) \cdots(\infty)\right) \rightarrow \\
& \left(\mathrm{Cu}_{9} \mathrm{~S}_{8}\right)_{\mathrm{n}} \text { Nano-whisker }+36 \mathrm{n}\left(\mathrm{NH}_{3}\right) \uparrow
\end{aligned}
$$

When a solution including thioacetamide and copper sulfate pantahydrate is placed in an ultrasonic pool, a series of reactions such as equations marked as from (2) to (4) will happen because of instantaneous high temperature and high pressure in the "cavitation" generated by ultrasonic wave. The way has proved by the appearance of $\mathrm{H}_{2} \mathrm{~S}$ and $\mathrm{CH}_{3} \mathrm{CONH}_{2}$ during the reaction. We suppose that the instantaneous high temperature and high pressure in the so-called cavitation produced by ultrasonic wave are important, although the details of formation of $\mathrm{Cu}_{9} \mathrm{~S}_{8}$ are not clearly understood now.

In summary, whisker-like $\mathrm{Cu}_{9} \mathrm{~S}_{8}$ nanocrystal has been successfully synthesized from thioacetamide and copper sulfate pentahydrate by ultrasonic irradiation route. The effect of reaction medium on morphology of the product is investigated in this letter. And optical properties of the product are studied with $\mathrm{UV}-\mathrm{vis}$ and PL spectra. A possible reaction mechanism is suggested.

We are grateful for the support of the Young Fund of University of Science and Technology of China and National Natural Science Foundation of China (No. 29804010) and Professor Liu in Structure Research Center for his help in study on TEM.

\section{References}

1 XRD measurement was carried out with a Phipis PQ1720 X-ray diffractionmeter with $\mathrm{Cu} \mathrm{K} \alpha$ irradiation $(\lambda=1.54178 \mathrm{~nm})$. TEM images were observed on a Hitachi Model H-800 transmission electron microscope under $200 \mathrm{kV}$ accelerating voltage. The absorption spectra were examined on an UV-2100 Schimadzu UV-vis spectrophotometer. The PL spectrum was measured on a Hitachi 850fluorescence spectrophotometer.

2 a) N. Heron, J. C. Calabrese, W. E. Farneth, and U. Wang, Science, 259, 1426 (1993). b) S. Foglia, L. Suber, and M. Righini, Colloid Surf., 177, 3 (2001). c) S. William, J. Rees, and K. Getrud, J. Mater. Res., 11, 3005 (1996). d) H. N. Cui and S. Q. Xi, Thin Solid Films, 288, 325 (1996). e) T. Barfels, H. J. Fitting, A. Gulans, J. Jansons, M. Springis, H. Stolz, I. Tale, and A. Veispals, Radiat. Meas., 33, 709 (2001). f) J. X. Chen and A. Z. Li, Mater. Sci. Eng., B, 75, 115 (2000).

3 a) A.P. Alivisatos, Science, 271, 933 (1996) b) S. J. Tans, M. H. Devoret, H. Dai, A. Thess, R. E. Smalley, L. J. Geerligs, and C. Dekker, Nature, 386, 474 (1997). c) S. Frank, P. Poncharal, Z. L. Wang, and W. A. D. Heer, Science, 280, 1744 (1998). d) J. R. Heath, P. J. Kuekes, G. Snyder, and R. S. Williams, Science, 280, 717 (1998). e) J. Hu, M. Ouyang, P. Yang, and C. M. Lieber, Nature, 399, 48 (1999).

4 a) T. Howard and J. R. Evans, Science, 203, 356 (1979). b) H. Y. Peng, X. T. Zhou, N. Wang, Y. F. Zheng, L. S. Liao, W. S. Shi, C. S. Lee, and S. T. Lee, Chem. Phys. Lett., 327, 263 (2000).

5 a) K. S. Suslick, Annu. Rev. Mater. Sci., 29, 295 (1999). b) J. Zhu, Y. Koltyin, and A. Gedanken, Chem. Mater., 12, 73 (2000). c) Y. Matai, R. Polsky, Y. Koltypin, and A. Gedanken., Chem. Mater., 12, 143 (2000). d) B. Li, Y. Xie, J. X. Huang, Y. Liu, and Y. T. Qian, Ultrason. Sonochem., 8, 331 (2001). e) H. S. Xia and Q. Wang, Chem. Mater., 14, 2158 (2002).

6 a) S. D. Wu, Z. G. Zhu, Z. P. Zhang, and L. Zhang, Mater. Sci. Eng., B, 90, 206 (2002). b) H. Y. Zhao, E. P. Douglas, B. S. Harrison, and K. S. Schanze, Langmuir, 17, $8428(2001)$

7 a) X. S. Peng, J. Zhang, X. F. Wang, Y. W. Wang, L. X. Zhao, G. W. Meng, and L. D. Zhang, Chem. Phys. Lett., 343, 470 (2001). b) Y. Xie, H. L. Su, B. Li, and Y. T. Qian, Mater. Res. Bull., 35, 675 (2000).

8 a) H. Wang, J. R. Zhang, and J. J. Zhu, J. Cryst. Growth, 233, 829 (2001). b) C. S Demoustier, E. Ferain, C. Jérôme, R. Jérôme, et al., Eur. Polym. J., 34, 1767 (1998).

9 a) R. J. Coustal, Chem. Phys., 238, 277 (1958). b) I. P. Parkin, Chem. Soc. Rev., 25 , 199 (1996). c) T. Ohtani, M. Motoki, K. Koh, and K. Ohshima, Mater. Res. Bull., 30, 1495 (1995). d) H. C. Yi and J. J. Moore, J. Mater. Sci., 25, 1159 (1990). e) M. Kemmler, M. Lazell, and P. O'Brien, J. Mater. Sci.: Mater. Electron., 13, 531 (2002). f) Q. Y. Lu, F. Gao, and D. Y. Zhao, Nano Lett., 2, 725 (2002)

10 M. Savelli and J. Bougnot, Top. Appl. Phys., 31, 213 (1979).

11 V. N. Konev, V. N. Chebotin, and S. A. Fomenkov, Inorg. Mater., 21, 166 (1985).

12 V. M. Glazov, O. D. Shchelikov, and A. S. Burkhanov, Inorg. Mater., 25, 633 (1989).

13 M. Dachraoui and J. Vedel, Sol. Cells, 22, 187 (1987).

14 W. Liang and M. H. Whangbo, Solid State Commun., 85, 405 (1993).

15 K. R. Allen, Met. Finish., 97, 172 (1999).

16 X. C. Jiang and Y. Xie, J. Mater. Chem., 10, 2193 (2000). 